\title{
Effects of nitrogen deposition on carbon cycle in terrestrial ecosystems of China: A meta-analysis
}

\author{
Hao Chen ${ }^{\text {a, b }}$, Dejun Li ${ }^{b}$, Geshere A. Gurmesa ${ }^{\mathrm{a}, \mathrm{d}, \mathrm{f}}$, Guirui Yu ${ }^{\mathrm{c}}$, Linghao Li ${ }^{\mathrm{e}}$, Wei Zhang ${ }^{\mathrm{a}}$, \\ Huajun Fang ${ }^{\mathrm{c}}$, Jiangming Mo ${ }^{\mathrm{a}, *}$ \\ ${ }^{a}$ Key Laboratory of Vegetation Restoration and Management of Degraded Ecosystems, South China Botanical Garden, Chinese Academy of Sciences, \\ Guangzhou 510650, China \\ ${ }^{\mathrm{b}}$ Huanjiang Observation and Research Station for Karst Ecosystem, Key Laboratory of Agro-ecological Processes in Subtropical Region, Institute of \\ Subtropical Agriculture, Chinese Academy of Sciences, Changsha 410125, China \\ ${ }^{\mathrm{c}}$ Institute of Geographical Sciences and Natural Resources Research, Chinese Academy of Sciences, Beijing 100101, China \\ ${ }^{\mathrm{d}}$ Department of Geosciences and Natural Resource Management, University of Copenhagen, Rolighedsvej 23, DK-1958 Frederiksberg C, Denmark \\ e State Key Laboratory of Vegetation Environmental Change, Institute of Botany, Chinese Academy of Sciences, Xiangshan, Beijing 100093, China \\ ${ }^{\mathrm{f}}$ Sino-Danish Center for Education and Research, Niels Jensens Vej 2, DK-8000 Aarhus C, Denmark
}

\section{A R T I C L E I N F O}

\section{Article history:}

Received 2 April 2015

Received in revised form

11 July 2015

Accepted 19 July 2015

Available online 30 July 2015

\section{Keywords:}

Nitrogen deposition

Carbon cycle

Global change

$\mathrm{N}$-rich and $\mathrm{N}$-limited ecosystems

Meta-analysis

China

\begin{abstract}
A B S T R A C T
Nitrogen $(\mathrm{N})$ deposition in China has increased greatly, but the general impact of elevated $\mathrm{N}$ deposition on carbon (C) dynamics in Chinese terrestrial ecosystems is not well documented. In this study we used a meta-analysis method to compile 88 studies on the effects of $\mathrm{N}$ deposition $\mathrm{C}$ cycling on Chinese terrestrial ecosystems. Our results showed that $\mathrm{N}$ addition did not change soil $\mathrm{C}$ pools but increased above-ground plant $C$ pool. A large decrease in below-ground plant $C$ pool was observed. Our result also showed that the impacts of $\mathrm{N}$ addition on ecosystem $\mathrm{C}$ dynamics depend on ecosystem type and rate of $\mathrm{N}$ addition. Overall, our findings suggest that 1 ) decreased below-ground plant $\mathrm{C}$ pool may limit long-term soil $\mathrm{C}$ sequestration; and 2 ) it is better to treat $\mathrm{N}$-rich and $\mathrm{N}$-limited ecosystems differently in modeling effects of $\mathrm{N}$ deposition on ecosystem $\mathrm{C}$ cycle.
\end{abstract}

() 2015 Elsevier Ltd. All rights reserved.

\section{Introduction}

Global atmospheric nitrogen $(\mathrm{N})$ deposition has dramatically increased due to extensive use of fossil fuels in industries and transportation, heavy application of fertilizers in agriculture, and expansion of animal husbandry (Galloway et al., 2004). Elevated N deposition is likely to change global carbon (C) cycles (Chapin et al., 2009) because $\mathrm{N}$ and $\mathrm{C}$ cycles are interdependent forming the basis of biogeochemical cycles and energy flows. A number of simulated field studies have been conducted in the past decades to investigate the effects of $\mathrm{N}$ deposition on ecosystem $\mathrm{C}$ cycles (Hogberg et al., 2006; Hyvonen et al., 2008; Pregitzer et al., 2008). Several metaanalysis studies have synthesized the available information to determine how ecosystem $\mathrm{C}$ pools and processes respond to $\mathrm{N}$

\footnotetext{
* Corresponding author.

E-mail address: mojm@scib.ac.cn (J. Mo).
}

deposition at a global scale (LeBauer and Treseder, 2008; Lu et al., 2011; Xia and Wan, 2008). These studies have greatly improved our understanding regarding consequences of $\mathrm{N}$ deposition on $\mathrm{C}$ cycling and indicated a strong regional diversity in the response of ecosystem $\mathrm{C}$ to $\mathrm{N}$ deposition at a global scale.

China, the second-largest world economy, has undergone rapid economic development with an average annual GDP growth of 9.1 percent during 1989-2014 (NBSC, 2014). This rapid development has caused serious environmental issues. The latest data show that China contributed $29 \%$ of the total 36 billion tonnes carbon emitted from all human sources in 2013 (Friedlingstein et al., 2014). N deposition in China has also been among the greatest globally (Liu et al., 2013). The averaged $\mathrm{N}$ deposition rate in China has increased from $13.2 \mathrm{~kg} \mathrm{~N} \mathrm{ha}^{-1}$ in the $1980 \mathrm{~s}$ to $21.1 \mathrm{~kg} \mathrm{~N} \mathrm{ha}^{-1}$ in the $2000 \mathrm{~s}$ and is projected to increase in the coming decades (Liu et al., 2013). On the other hand, China also has experienced regionally distinct landuse histories and climate trends (Piao et al., 2009). Hence the degree of $\mathrm{N}$ deposition and its potential effects on the $\mathrm{C}$ cycle in 
Chinese terrestrial ecosystems should be different and are of increasing global concern due to the increasing interest in regional aspects of the global C cycle (Piao et al., 2009). Several N deposition monitoring programs and increased $\mathrm{N}$ deposition simulation experiments have been conducted since the late 1990s (Mo et al., 2006; Niu et al., 2010; Tu et al., 2010; Xu et al., 2009). Liu et al. (2011) recently presented a description of the effects of $\mathrm{N}$ deposition on ecosystem $\mathrm{C}$ cycling in China. However, a synthetic analysis of $\mathrm{N}$ deposition impacts on $\mathrm{C}$ dynamics in Chinese terrestrial ecosystems remains lacking.

In the present study, we used a meta-analysis technique to synthesize all the available information in China. Our main objectives were to: (1) quantify the responses of $C$ fluxes ( $C$ influx and efflux) and $C$ pool sizes (including plant, litter, microbe, soil, and dissolved organic $\mathrm{C}$ ) to experimental $\mathrm{N}$ addition; (2) examine whether ecosystem types, fertilization rates and fertilization forms influence the responses of ecosystem $\mathrm{C}$ fluxes and pools to $\mathrm{N}$ addition; and (3) reveal the shortage of the current $\mathrm{N}$ deposition research in China. Our study provides valuable information to environmental policy- and decision-makers in their attempts to curb $\mathrm{N}$ emissions to the atmosphere, and to evaluate the effects of $\mathrm{N}$ deposition on terrestrial ecosystems.

\section{Materials and methods}

\subsection{Data collection}

Publications that studied $\mathrm{C}$ cycle response to $\mathrm{N}$ addition (Supplementary Information Table S2) were selected by searching Web of Science (2000-2013) and China National Knowledge Infrastructure (CNKI). In addition, unpublished data from some studies known to us were collected. To avoid publication biases, the following four criteria were applied to select appropriate studies: (1) the study must contain at least one of our selected variables with a clear record of the ecosystem type, $\mathrm{N}$ application rate, $\mathrm{N}$ fertilization form, and experimental duration; (2) the $\mathrm{N}$ addition and control plots started with the same climatic, soil and vegetation conditions to reduce effects of confounding factors; (3) the means, standard deviations or standard errors and sample sizes of the target variables were directly reported or could be either calculated from data presented in the paper or extracted using Origin 8.0 software (Origin Lab Corporation, Northampton, MA, USA) if the data were graphically presented; (4) the study must not use $\mathrm{N}$ deposition gradients as in several other studies (Fang et al., 2011; Huang et al., 2012). Most of the studies used one-time measurement, but latest samplings were used if more than one measurements at different temporal scales were available for the same experiment (Liu and Greaver, 2009; Treseder, 2008). Measurements for different $\mathrm{N}$ application rates were considered as independent observations if more than one levels of $\mathrm{N}$ addition were applied in the same experiment (Liu and Greaver, 2009).

The compiled database contained 12 variables associated with ecosystem $C$ cycle, including $C$ fluxes (i.e., net photosynthesis rate (NPR), net primary productivity (NPP), litterfall, litter decomposition rate (mass loss or $[k]$ value), soil respiration, and ecosystem respiration), ecosystem $C$ pools in above- and below-ground plant biomass, microbial biomass (MBC), dissolved organic $C$ (DOC), organic horizon $(\mathrm{OH})$ and mineral soil $\mathrm{C}$. Data on $\mathrm{C}$ fluxes were obtained from studies where these data were directly reported. We used ecosystem respiration to replace soil respiration in grasslands because soil respiration is less measured in grasslands. Above- and below-ground plant $\mathrm{C}$ pools were determined by above-ground plant biomass or below-ground root biomass. Soil $\mathrm{C}$ pools were determined by soil $\mathrm{C}$ content or $\mathrm{C}$ storage. In addition, four supporting variables (i.e., soil inorganic $\mathrm{N}$, leaf $\mathrm{N}$, and soil $\mathrm{pH}$ ) were evaluated (Supplementary Information Table S3) to explain the results of the main variables above.

All the variables were compared among different ecosystem types, $\mathrm{N}$ addition forms, and $\mathrm{N}$ addition rates. Four ecosystem types (i.e. N-rich subtropical forests, N-limited subtropical forests, temperate forests and grasslands) were identified. These ecosystems were categorized into two main groups as $\mathrm{N}$-rich and $\mathrm{N}$ limited ecosystem based on their initial soil $\mathrm{N}$ level and information on plant growth response to experimental $\mathrm{N}$ addition. That is, the old-growth subtropical forests (Mo et al., 2008) and forests dominated by $\mathrm{N}$-fixing species (tree age $>30$ years) (Zhang et al., 2012) were grouped into $\mathrm{N}$-rich ecosystems as they have high soil $\mathrm{N}$ concentrations (Fang et al., 2008) and plant growth in these ecosystems is not limited by N availability (Lu et al., 2010). Early successional forests (Mo et al., 2007; Tu et al., 2010), temperate forests and grasslands, were grouped into $\mathrm{N}$-limited ecosystem because they have low soil $\mathrm{N}$ level and plant growth in these ecosystems is limited by $\mathrm{N}$ availability. $\mathrm{N}$ addition levels were classified into three classes, including low $\mathrm{N}\left(\mathrm{LN} ; \leq 60 \mathrm{~kg} \mathrm{~N} \mathrm{ha}^{-1} \mathrm{yr}^{-1}\right)$, medium N (MN; 61-120 kg N ha ${ }^{-1} \mathrm{yr}^{-1}$ ), and high $\mathrm{N}\left(\mathrm{HN} ;>120 \mathrm{~kg} \mathrm{~N} \mathrm{ha}^{-1} \mathrm{yr}^{-1}\right)$. In addition, we compared the variables only between two $\mathrm{N}$ fertilizer forms; $\mathrm{NH}_{4} \mathrm{NO}_{3}$ and urea which were the main fertilization forms in recent China's $\mathrm{N}$ deposition simulated experiments.

\subsection{Analysis of data}

The data were analyzed using meta-analysis method as described in Hedges et al. (1999). The effects of $\mathrm{N}$ addition on terrestrial ecosystem $\mathrm{C}$ pools and fluxes were estimated by response ratio (RR), which was calculated as:

$\mathrm{RR}=\ln \left(\overline{\mathrm{X}_{\mathrm{t}}} / \overline{\mathrm{X}_{\mathrm{c}}}\right)=\ln \left(\overline{\mathrm{X}_{\mathrm{t}}}\right)-\ln \left(\overline{\mathrm{X}_{\mathrm{c}}}\right)$

where $\left(\overline{\mathrm{X}_{\mathrm{t}}}\right)$ and $\left(\overline{\mathrm{X}_{\mathrm{c}}}\right)$ are the mean values of a given variable in the treatment and the control group, respectively. The natural log was used for meta-analyses because its bias is small and its sampling distribution is approximately normal (Luo et al., 2006). The variance $(v)$ of RR was estimated as:

$v=\frac{\mathrm{s}_{\mathrm{t}}^{2}}{\mathrm{n}_{\mathrm{t}} \overline{\mathrm{X}_{\mathrm{t}}^{2}}}+\frac{\mathrm{S}_{\mathrm{c}}^{2}}{\mathrm{n}_{\mathrm{c}} \overline{\mathrm{X}_{\mathrm{c}}^{2}}}$

where $\mathrm{n}_{t}$ and $\mathrm{n}_{c}$ are the sample sizes for the treatment and control groups, respectively; and $s_{t}$ and $s_{c}$ are the standard deviations for the treatment and control groups, respectively.

To test whether the experimental conditions alter the response magnitude to $\mathrm{N}$ addition, each observation was categorized into three groups: ecosystem type, $\mathrm{N}$ addition rate, and forms of $\mathrm{N}$ addition. The data were sub-divided and the mean of response ratio $\left(\mathrm{RR}_{++}\right)$and standard error $\left[\mathrm{s}\left(\mathrm{RR}_{++}\right)\right]$were calculated as:

$$
\begin{gathered}
\mathrm{RR}_{++}=\frac{\sum_{i=1}^{m} \sum_{j=1}^{k_{i}} W_{i j} \mathrm{RR}_{i j}}{\sum_{i=1}^{m} \sum_{j=1}^{k_{i}} W_{i j}} \\
\mathrm{~s}\left(\mathrm{RR}_{++}\right)=\sqrt{\frac{1}{\sum_{i=1}^{m} \sum_{j=1}^{k_{i}} W_{i j}}}
\end{gathered}
$$

where $m$ is the number of groups (e.g., different $\mathrm{N}$ addition levels, $\mathrm{N}$ forms or ecosystem types), $\mathrm{k}_{i}$ is the number of comparisons in the $i$ th group, and $W_{i j}$ is the weighting factor and was estimated as: 


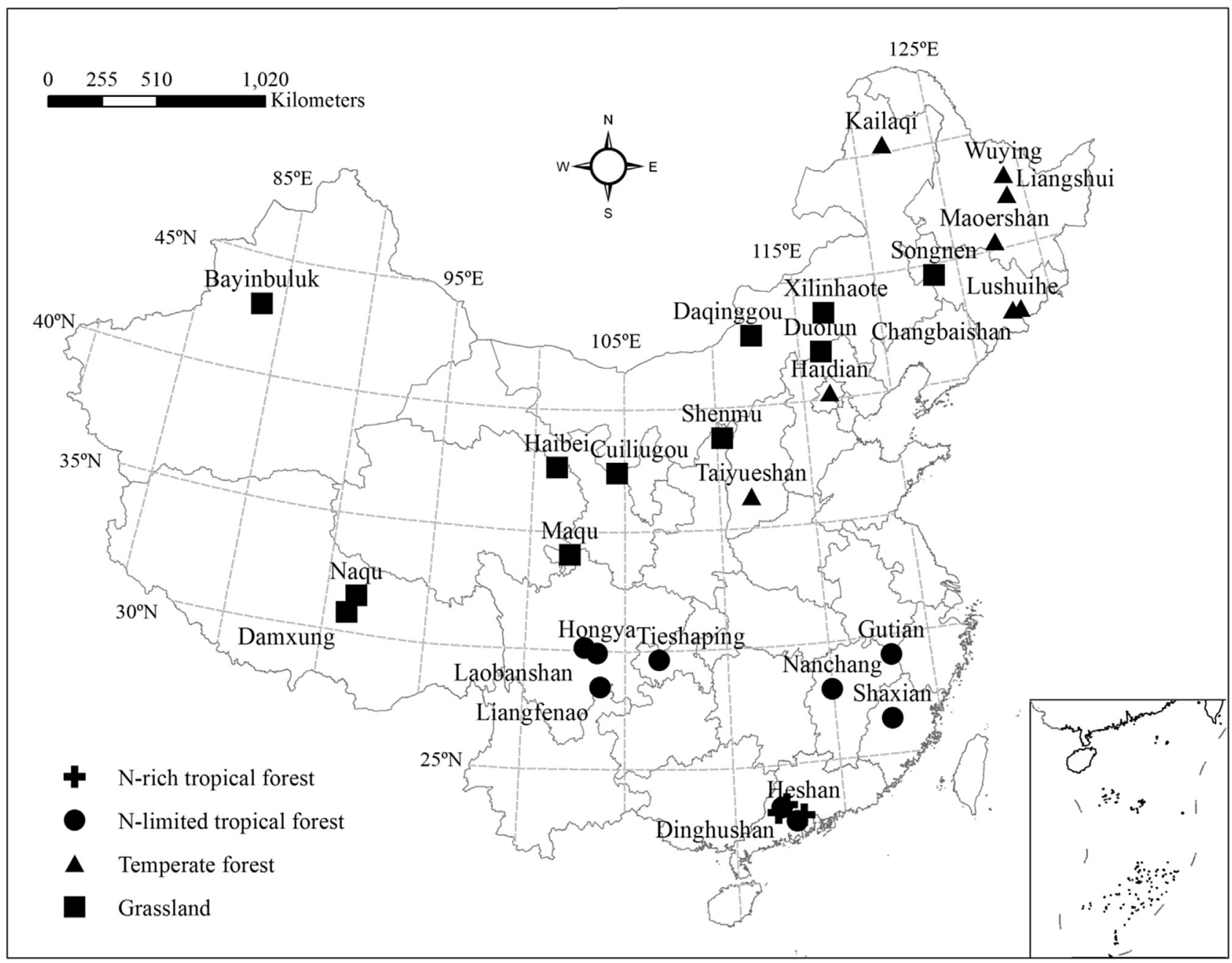

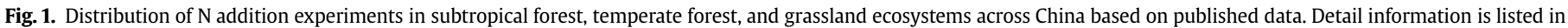
Supplementary Information Table S1.

$W_{i j}=\frac{1}{v}$

The $95 \%$ confidence interval $(\mathrm{CI})$ for the response ratio was given as:

Table 1

Distribution of all collected data among different ecosystem types, $\mathrm{N}$ fertilization duration, $\mathrm{N}$ fertilization forms, and $\mathrm{N}$ fertilization rates. $\mathrm{HN}=$ high $\mathrm{N}$ addition; $\mathrm{MN}=$ medium $\mathrm{N}$ addition; $\mathrm{LN}=$ Low $\mathrm{N}$ addition.

\begin{tabular}{lrl}
\hline & Observation numbers & Percentage (\%) \\
\hline Ecosystem types & & \\
$\quad$ Subtropical forest (N-rich) & 98 & 16.1 \\
Subtropical forest (N-limited) & 217 & 35.7 \\
Temperate forest & 88 & 14.5 \\
$\quad$ Grassland & 204 & 33.6 \\
$\mathrm{~N}$ fertilization duration & & \\
$\quad$ - 4 yr & 519 & 85.5 \\
$5-10$ yr & 88 & 14.5 \\
$\mathrm{~N}$ fertilization forms & & \\
NH $\mathrm{NO}_{3}$ & 445 & 73.3 \\
Urea & 131 & 21.6 \\
Others & 31 & 5.1 \\
$\mathrm{~N}$ fertilization rates & & \\
HN & 192 & 31.6 \\
$\mathrm{MN}$ & 171 & 28.2 \\
$\mathrm{LN}$ & 244 & 40.2 \\
\hline
\end{tabular}

$95 \% \mathrm{CI}=\mathrm{RR}_{++} \pm 1.96 \mathrm{~s}\left(\mathrm{RR}_{++}\right)$

If the $95 \% \mathrm{CI}$ values of $\mathrm{RR}_{++}$for a variable did not cover zero, the effects of $\mathrm{N}$ addition on the variable were considered to differ significantly between treatments.

The meta-analysis was conducted using the METAWIN (Sinauer Associates, Inc. Sunderland, MA, USA). We also used a one-way ANOVA to examine whether the $\mathrm{RR}_{++}$of a variable differed significantly between ecosystem types, and among different $\mathrm{N}$ addition rates or forms. For a better explanation, mean of the response ratio $\left(R R_{++}\right)$was transformed back to the percentage change calculated by the formula: $\left(e^{\mathrm{RR}_{++}}-1\right) \times 100 \%$.

\section{Results}

\subsection{Data overview}

Our meta-analysis study compiled data form 88 studies that included 607 observations at 33 sites (Fig. 1), and all were natural ecosystems. Four types of ecosystems were included in the analysis: $\mathrm{N}$-rich subtropical forest $(\mathrm{n}=98), \mathrm{N}$-limited subtropical forest $(\mathrm{n}=217)$, temperate forest $(\mathrm{n}=88)$, and grassland $(\mathrm{n}=204)$ (Table 1 ). In total 12 response variables were extracted from the selected studies. However, not all variables were measured at all the sites. The missing variables include NPR and litterfall in grassland; 
(a) Net photosynthesis rate

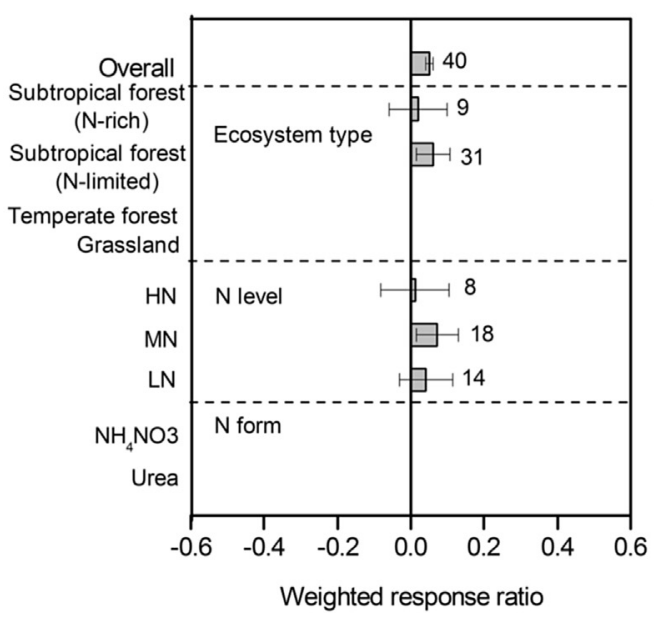

(c) Litterfall

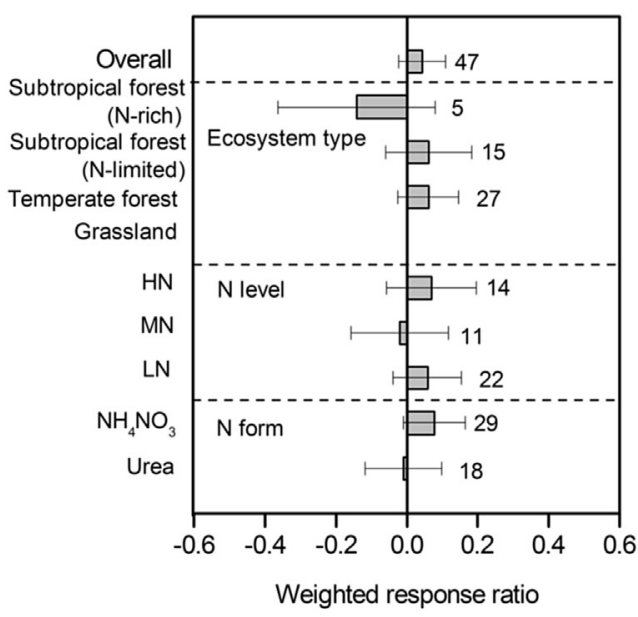

(e) Ecosystem respiration

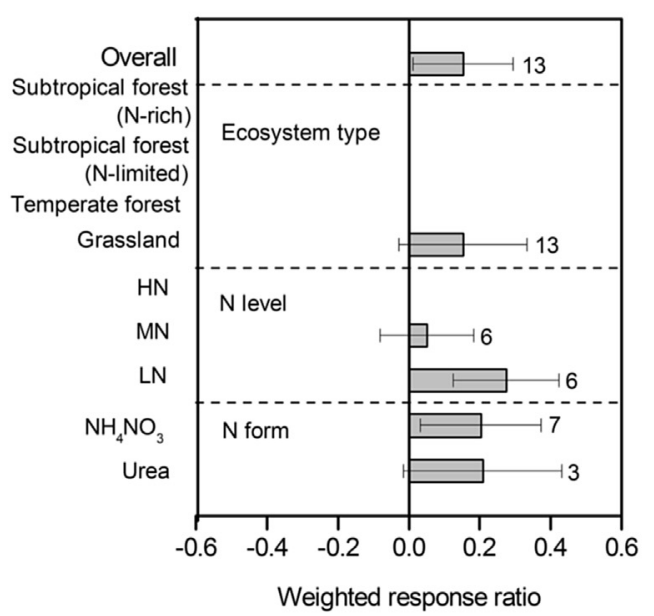

(b) Net primary productivity

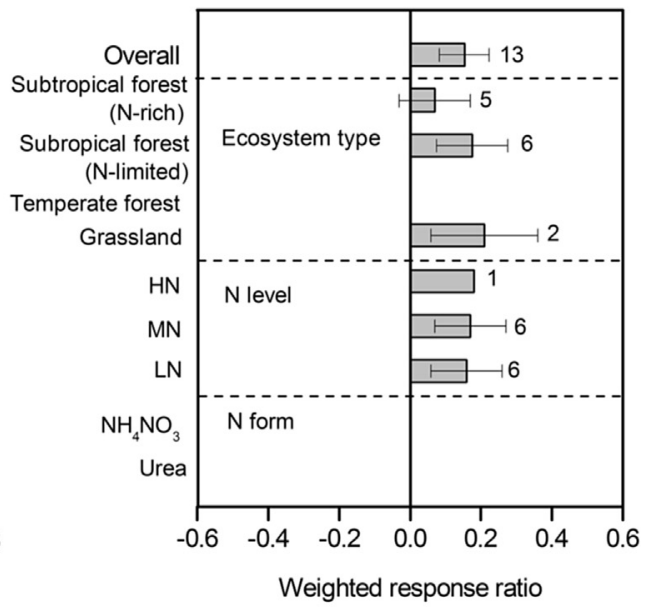

(d) Litter decomposition

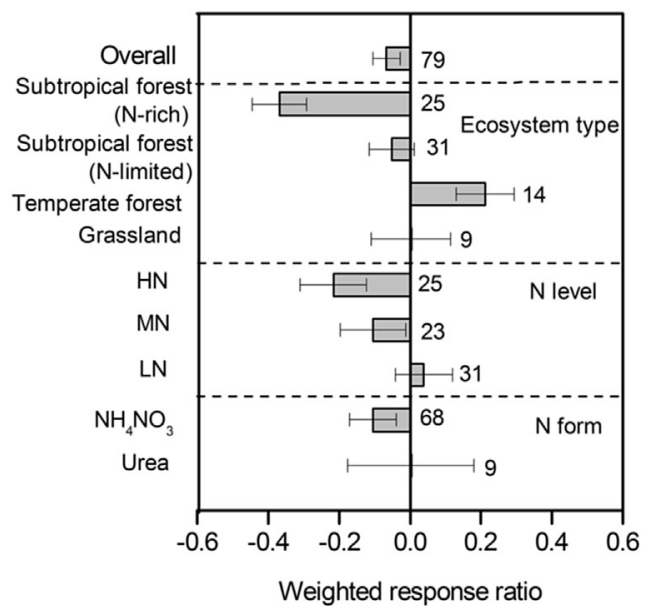

(f) Soil respiration

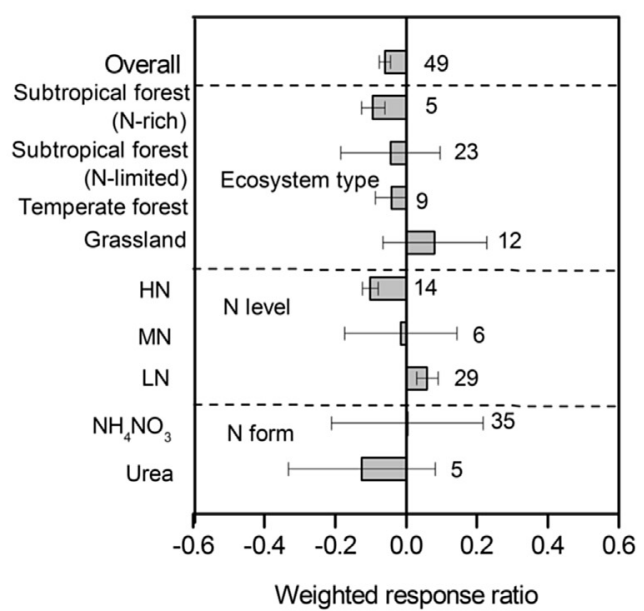

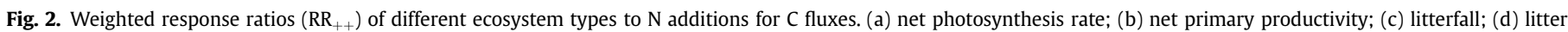

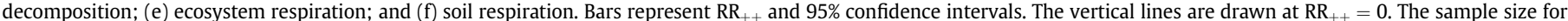
each variable is shown next to the bar.

NPR, NPP, above-ground plant $\mathrm{C}$ and $\mathrm{OH}$ soil $\mathrm{C}$ pools in temperate forest. Similarly, ecosystem respiration was measured only in grasslands (Figs. 2 and 3). The fertilization duration in all selected studies lasted up to 10 years and fertilization durations in $85.5 \%$ of studies were $\leq 4$ years (Table 1 ). The $\mathrm{N}$ addition rates ranged from 10 to $640 \mathrm{~kg} \mathrm{~N} \mathrm{ha}^{-1}$ year $^{-1}$, and the $\mathrm{N}$ fertilizer forms included $\mathrm{NH}_{4} \mathrm{NO}_{3}$ (counting for $73.3 \%$ ), urea (counting for $21.6 \%$ ) and others (such as $\mathrm{NaNO}_{3}$, and $\left(\mathrm{NH}_{4}\right)_{2} \mathrm{SO}_{4}$ and mixed fertilizer) (Table 1 ). 
(a) Above-ground plant C pool

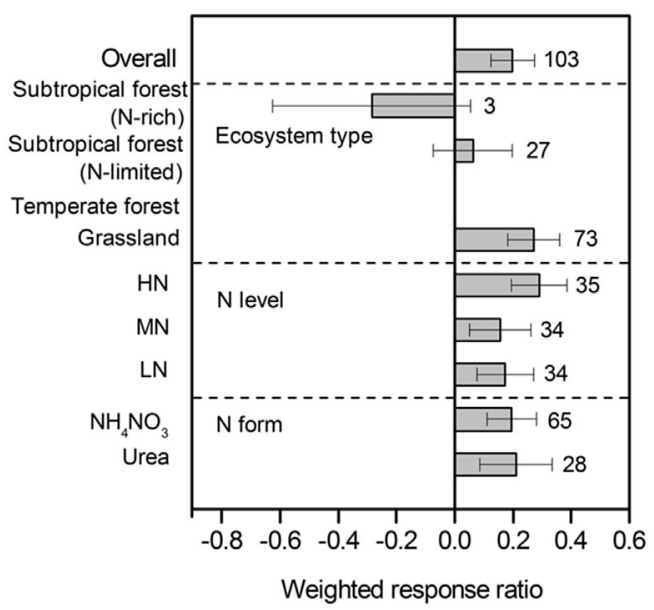

(c) MBC

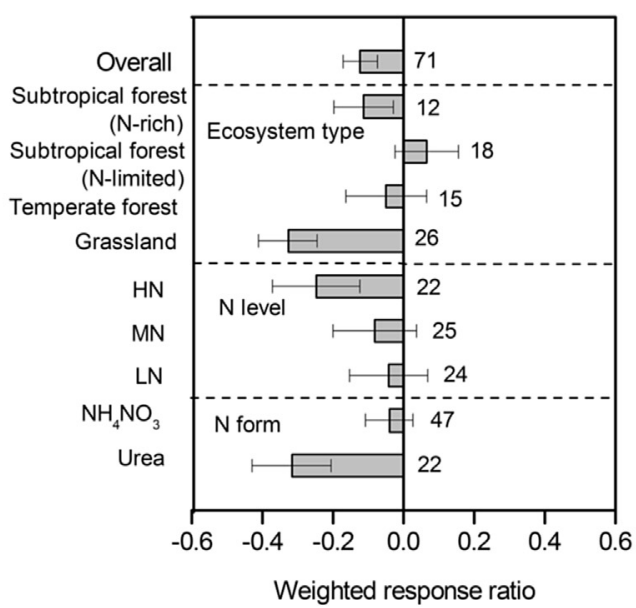

(e) OH soil C pool

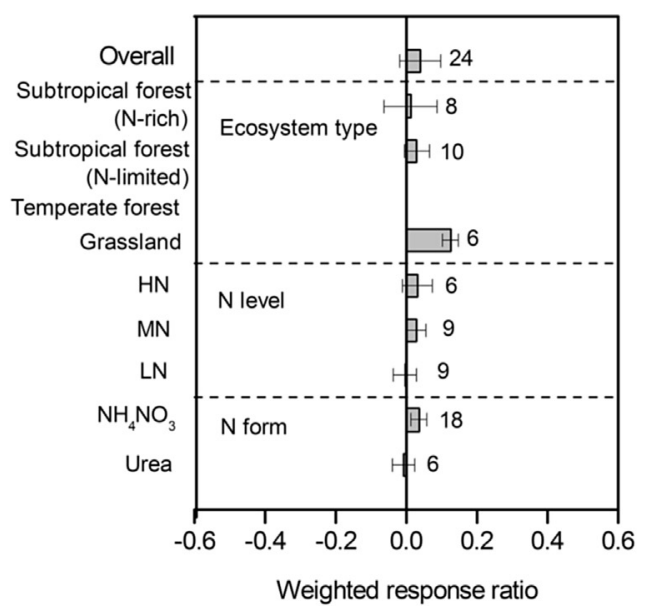

(b) Below-ground plant C pool

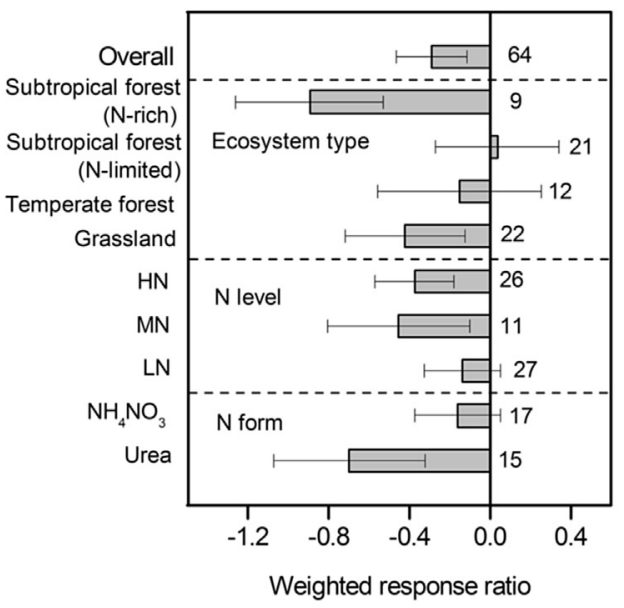

(d) DOC

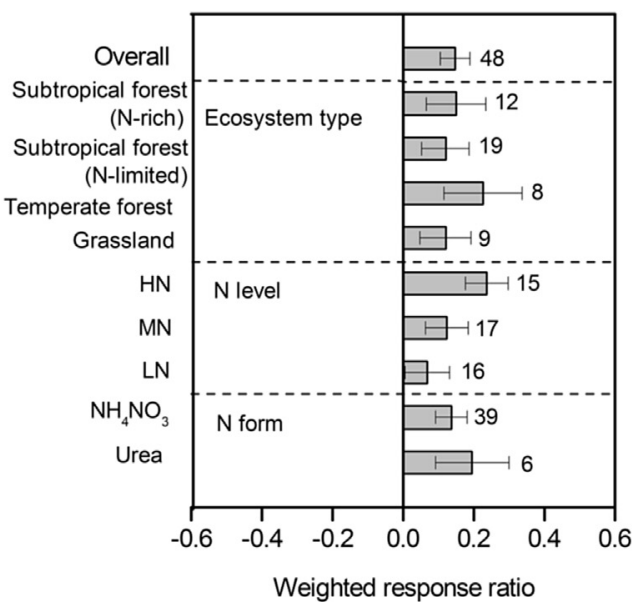

(f) Mineral soil C pool

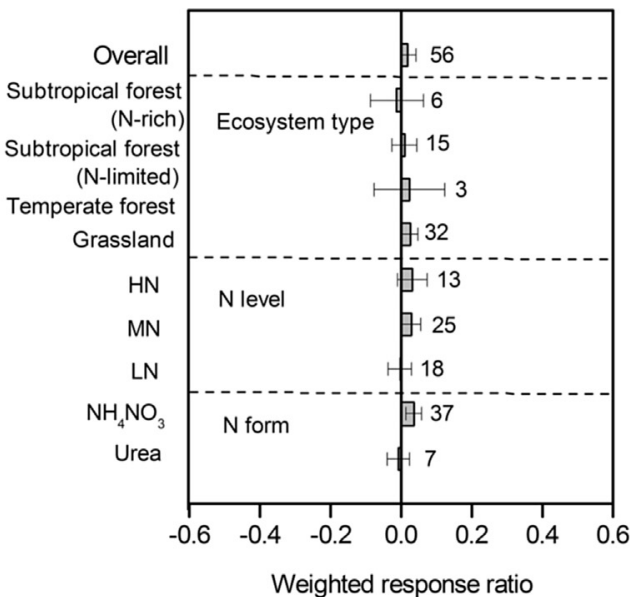

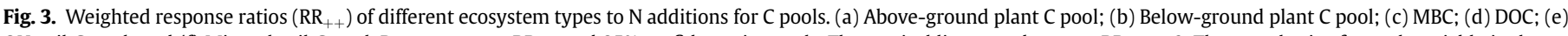

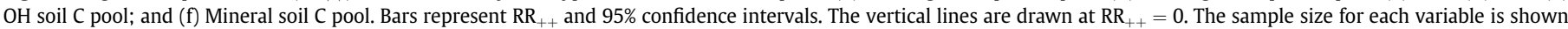
next to the bar. 
Table 2

Percentage changes and sample size of the selected 16 variables related to carbon cycle. The response of ecosystem respiration is only for the grassland.

\begin{tabular}{lcc}
\hline Variable & Percentage change (\%) & Sample size (n) \\
\hline Carbon C fluxes & & \\
Net photosynthetic rate & 5.2 & 40 \\
Net primary productivity & 10.3 & 13 \\
Litterfall & 4.4 & 47 \\
Litter decomposition & -6.4 & 79 \\
Soil respiration & -5.3 & 13 \\
Ecosystem respiration & 19.7 & 49 \\
Carbon pool & & \\
Above-ground plant C pool & 21.9 & 103 \\
Below-ground Plant C pool & -25.0 & 64 \\
Microbial biomassC pool & -11.6 & 71 \\
Dissolved organic C & 15.8 & 48 \\
OH soil C pool & 3.8 & 24 \\
Mineral soil C pool & 1.9 & 56 \\
Others & & 43 \\
Soil inorganic N & 85.9 & 35 \\
Leaf N & 35.6 & 34 \\
Soil pH & -6.4 & \\
\hline
\end{tabular}

\section{2. $N$ addition effects on $C$ fluxes and $C$ pools}

$\mathrm{N}$ addition-induced changes in $\mathrm{C}$ fluxes showed large variation. Compared with control groups, NPR and NPP were significantly increased by $5.2 \%$ and $10.3 \%$, respectively under experimental $\mathrm{N}$ addition (mean effect size $=0.051$ and 0.154 ; CI: 0.01 to 0.09 , and 0.04 to 0.26 ; Table 2, Fig. 2a,b). Litterfall was increased by $4.4 \%$ (mean effect size $=0.043 ; \mathrm{CI}$ : -0.02 to 0.11 ; Table 2, Fig. $2 \mathrm{c}$ ) but the change was statistically not significant. $\mathrm{N}$ addition significantly decreased litter decomposition (mean effect size $=-0.066$; CI: -0.10 to -0.02 ; Table 2, Fig. 2 d) and soil respiration (mean effect size $=-0.059$; CI: -0.16 to -0.07 ; Table 2 , Fig. 2 f) by $6.4 \%$ and $5.3 \%$, respectively, across all ecosystems, but it significantly increased ecosystem respiration by $19.7 \%$ in grasslands (mean effect size $=0.15 ; \mathrm{CI}: 0.05$ to 0.24 ; Table 2, Fig. 2e).

Changes in $\mathrm{C}$ stock due to $\mathrm{N}$ addition varied among ecosystem pools. $\mathrm{N}$ addition significantly increased above-ground plant $\mathrm{C}$ pool (mean effect size $=0.198 ; \mathrm{CI}: 0.12$ to 0.27 ; Table 2, Fig. 3a) and DOC (mean effect size $=0.146$; CI: 0.10 to 0.19 ; Table 2, Fig. $3 \mathrm{~d}$ ) by $21.9 \%$ and $15.8 \%$, respectively. However, $\mathrm{N}$ addition significantly decreased below-ground plant $C$ (mean effect size $=-0.287$; CI: -0.46 to -0.11 ; Table 2, Fig. $3 \mathrm{~b}$ ) and $\mathrm{MBC}$ (mean effect size $=0.123$; CI: -0.17 to -0.07 ; Table 2 , Fig. 3 c) by $25.0 \%$ and $11.6 \%$, respectively. $\mathrm{OH}$ soil $\mathrm{C}$ pool exhibited only a minor increase (mean effect size $=0.039$; $\mathrm{CI}:-0.02$ to 0.08 ; Table 2, Fig. 3e), and no effect of $\mathrm{N}$ addition on mineral soil $\mathrm{C}$ pool was observed across all ecosystems (mean effect size $=0.019 ; \mathrm{CI}$ : -0.01 to 0.03 ; Table 2 , Fig. 3f).

\subsection{Variation between $\mathrm{N}$-rich and $\mathrm{N}$-limited ecosystems}

Despite the general trends observed above, responses of some measured variables to $\mathrm{N}$ addition greatly varied between $\mathrm{N}$-rich and $\mathrm{N}$-limited ecosystems. For example, changes in above-ground plant C, litterfall, litter decomposition, soil respiration, belowground plant $\mathrm{C}$ and $\mathrm{MBC}$ after $\mathrm{N}$ addition were significantly different between these two groups (Fig. $3 \mathrm{a}-\mathrm{f}$; $P<0.01$ for all), showing decreasing trends in $\mathrm{N}$-rich subtropical forest but increased trends in other $\mathrm{N}$-limited ecosystems. However, changes in some C fluxes (e.g. NPR, NPP) and C pools (e.g. OH soil C pool, mineral soil $\mathrm{C}$ pool and $\mathrm{DOC}$ ) for these two ecosystem types did not

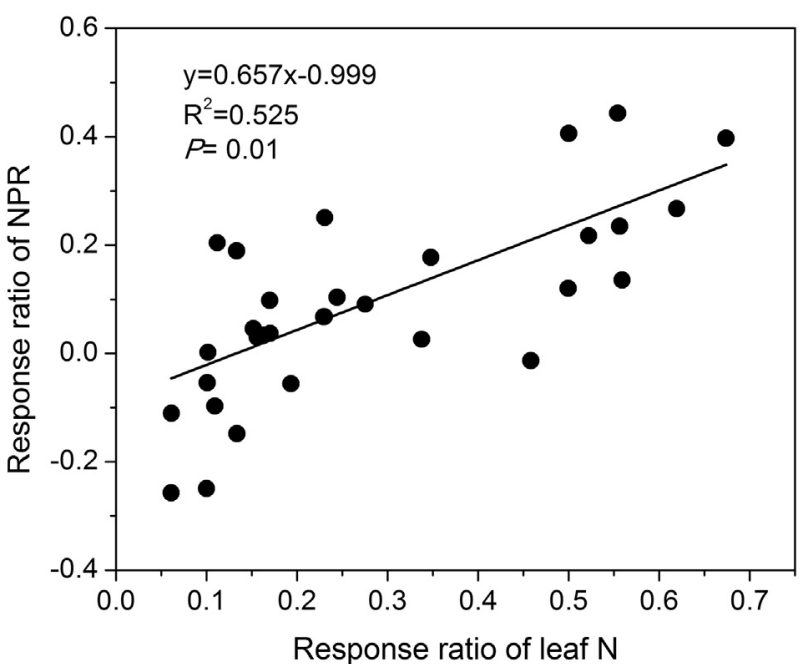

Fig. 4. Relationships between response ratios of leaf $\mathrm{N}$ and net photosynthesis rate [NPR].

differ from the general trends observed.

\subsection{Effects of different fertilization rates and fertilizer forms}

Fertilization rate influenced the responses of $\mathrm{C}$ fluxes and $\mathrm{C}$ pools to $\mathrm{N}$ addition. For example, litter decomposition and soil respiration were significantly different between $\mathrm{N}$ addition levels (Fig. 2d, f; both $P<0.01$ ), which decreased under MN and HN treatments but increased under LN treatment. Below-ground plant $\mathrm{C}$ pool, $\mathrm{MBC}$ and $\mathrm{DOC}$ were found to decrease under $\mathrm{N}$ addition, but their decreasing extents were significantly larger under MN treatment and HN treatment than those under LN treatment (Fig. 3b, d; $P<0.01$ for both). Other variables showed a similar response to $\mathrm{N}$ addition under different fertilization rate. However, except for MBC, we did not find any differences between $\mathrm{N}$ fertilization forms in all variables.

\subsection{Effects of $N$ additions on other variables}

Soil inorganic $\mathrm{N}$ and leaf $\mathrm{N}$ concentrations were significantly increased by $85.9 \%$ and $35.6 \%$ (Table 2, mean effect size $=0.62$ and 0.30 ; CI: 0.53 to 0.71 , and 0.23 to 0.38 , respectively), respectively. Soil $\mathrm{pH}$ was significantly decreased by $6.4 \%$ compared to control treatment (Table 2, mean effect size $=-0.28$; $\mathrm{CI}$ : -0.08 to -0.48 ). Correlation analysis showed that there was a significant relationship between leaf $\mathrm{N}$ and net photosynthesis rate (Fig. $4, P=0.01$ ).

\section{Discussion}

\subsection{Responses of $C$ storage and fluxes to $N$ addition}

Nitrogen addition led to a significant increase in above-ground plant $C$ pool and a slight increase in litter production (Fig. 2c and Fig. 3a) which is likely due to stimulated plant growth. Our results are consistent with previous findings in meta-analysis studies on effects of $\mathrm{N}$ addition on above-ground plant growth (LeBauer and Treseder, 2008; Xia and Wan, 2008), gradient analysis (Laubhann et al., 2009; Solberg et al., 2009; Thomas et al., 2010), and model simulation (Wamelink et al., 2009a, 2009b). The increased aboveground plant $C$ pool could be attributed to the enhanced NPP (Fig. 2) which could, in turn, be attributed to improved soil $\mathrm{N}$ availability to support plant growth as suggested by several studies (Pregitzer et al., 2008; Vitousek and Howarth, 1991). Increased N 


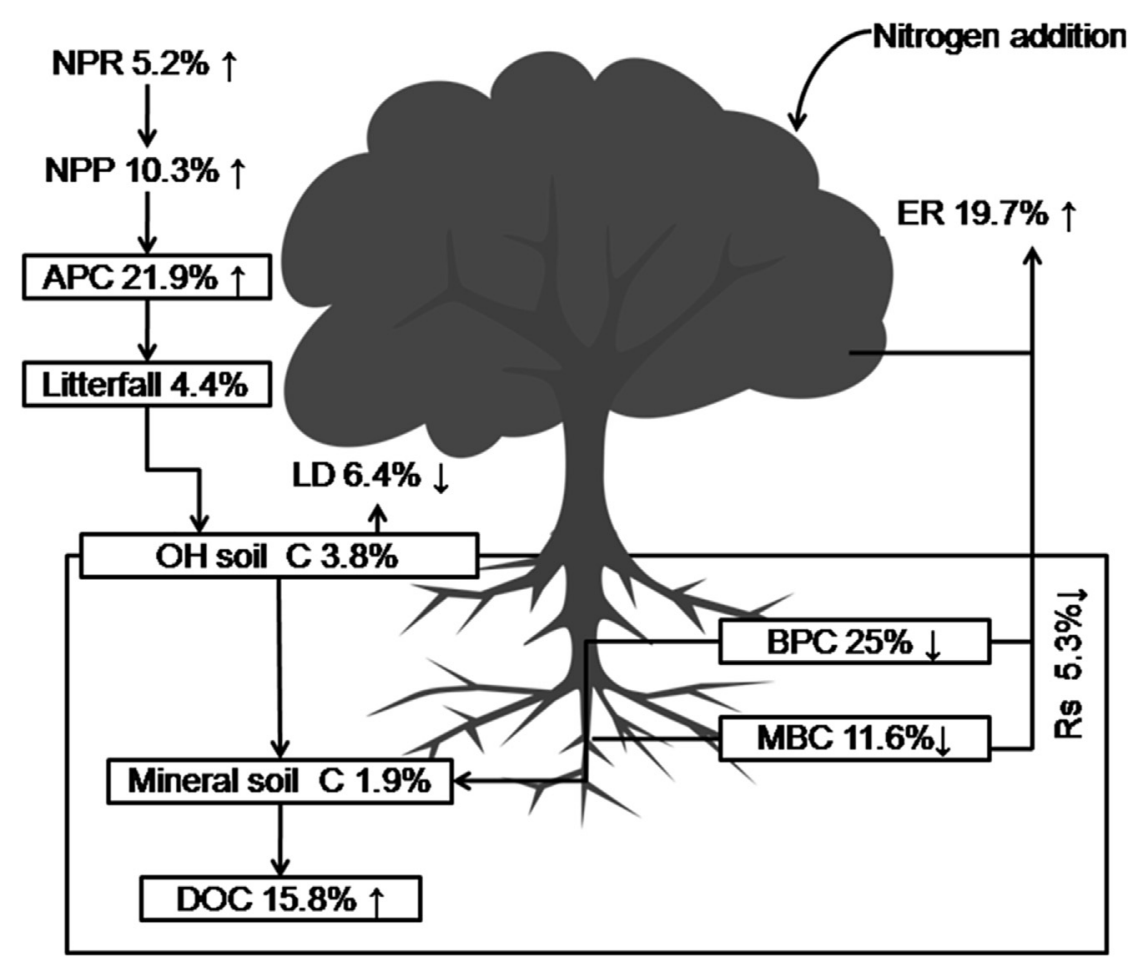

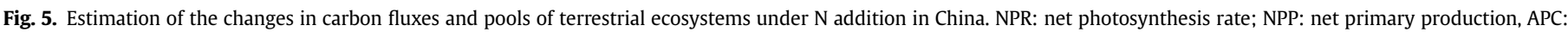

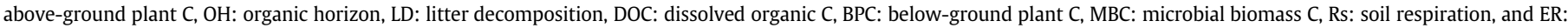
ecosystem respiration. The short arrows $\uparrow$ and $\downarrow$ represent significant increase and significant decrease in $\mathrm{C}$ processes in response to $\mathrm{N}$ addition, respectively.

availability to plants due to $\mathrm{N}$ addition is evident in our analysis as indicated by the significant increase in soil inorganic $\mathrm{N}\left(\mathrm{NH}_{4}^{+}\right.$plus $\mathrm{NO}_{3}^{-}$) and leaf $\mathrm{N}$ content by $85.9 \%$ and $35.6 \%$, respectively (Table 2). The significant positive relationship between the leaf $\mathrm{N}$ concentration and plant photosynthesis we found (Fig. 4) supports the above explanation.

However, $\mathrm{N}$ addition has no effect on soil $\mathrm{C}$ pools (in both $\mathrm{OH}$ and mineral soil C) in this study (Fig. 2, Table 1). This is consistent with a previous suggestion from a meta-analysis study (Lu et al., 2011 ) that $\mathrm{N}$ addition had minor influence on $\mathrm{C}$ pools of $\mathrm{OH}$ or mineral horizons across global forests and grasslands. However, other reviews and meta-analyses showed that $\mathrm{N}$ fertilization increased soil C storage (Hyvonen et al., 2008; Janssens et al., 2010; Nave et al., 2009), and increased C pool in $\mathrm{OH}$ but not in mineral horizons were reported elsewhere (Liu and Greaver, 2010).

In terrestrial ecosystems, any changes in soil C pool are generally related to the changes in $C$ fluxes. In this study, we found that adding $\mathrm{N}$ increased litterfall and decreased both litter decomposition and soil respiration (Fig. 5), which all suggest potentially increase in soil $C$ sequestration. The increase in DOC concentration we observed (Fig. 3d) did not contribute to changes in soil $\mathrm{C}$ pool because DOC is low in soil and is generally suggested to have minor contribution for $\mathrm{C}$ sequestration.

The reason why soil $\mathrm{C}$ pools were not changed significantly by $\mathrm{N}$ addition is far from conclusion based on our data. It could be partly explained by the decrease in below-ground plant C (Fig. 3b) because dead roots are the main mechanism for soil $C$ inputs. Our result may suggest that reduced below-ground plant $\mathrm{C}$ under $\mathrm{N}$ addition may be an important factor for limiting long-term soil $\mathrm{C}$ sequestration. However, this needs further investigation because it contradicts results from previous meta-analysis studies (Xia and Wan, 2008; Lu et al., 2011) who reported that plant root biomass was increased by $23 \%$.

There are two potential explanations for the decrease in below- ground $C$ pool. First, plants invest less $C$ to roots because less effort is required to acquire this resource from the soil (Boxman et al., 1998; Haynes and Gower, 1995). Thus the reduction in belowground plant $\mathrm{C}$ by $\mathrm{N}$ addition may be the result of a $\mathrm{C}$ tradeoff between above-ground plant tissues (leaves) and below-ground plant tissues. In support of our explanation, previous studies suggested that $\mathrm{N}$ addition tended to reduce root: shoot ratio (Johnson and Thornley, 1987). We did also find that in grasslands above-ground plant $C$ increased but the below-ground plant $C$ decreased under $\mathrm{N}$ addition, which supports above explanation. However, this explanation does not seems to fit to other ecosystems, especially the N-rich subtropical forest where above- and below-ground plant both decreased. $\mathrm{N}$-addition induced soil acidification may be a better explanation for our finding. It has been suggested that $\mathrm{N}$ deposition will lead to soil acidification (Lu et al., 2010; Matson et al., 1999) which would reduce root biomass through directly causing root death (Godbold et al., 2003). In this study, we have found that $\mathrm{N}$ addition significantly decreased soil $\mathrm{pH}$ by $6.4 \%$ across all ecosystems (Table 2). In addition, the similar response trends in soil $\mathrm{pH}, \mathrm{MBC}$, and root biomass (Supplementary Information Fig. S1) suggest that $\mathrm{N}$-addition induced soil acidification did have direct damage to plant and microbe.

\subsection{Effects of ecosystem type and $N$ addition rate}

In this study, very different responses between N-rich subtropical forests and other $\mathrm{N}$-limited ecosystems were shown under $\mathrm{N}$ addition. In a previous meta-analysis study, the impact of $\mathrm{N}$ addition on ecosystem $\mathrm{C}$ dynamics has been found to largely depend on ecosystem types (Liu and Greaver, 2010); however, the difference between $\mathrm{N}$-rich and $\mathrm{N}$-limited ecosystems has not been presented in any previous meta-analysis studies. Our observation can be explained by $\mathrm{N}$ saturation hypotheses (Aber et al., 1998) because the two $\mathrm{N}$-rich forest types in our study, i.e., old-growth 
forests and N-fixing tropical plantation are both N- saturated systems as reported by previous studies (Mo et al., 2008; Zhang et al., 2012). N saturation hypotheses suggest that once an ecosystem reaches $\mathrm{N}$ saturation, further increase in $\mathrm{N}$ addition will not increase NPP of the ecosystem (Aber et al., 1998). This is in agreement with our meta-analysis results showing that experimental $\mathrm{N}$ addition significantly increased above-ground plant $\mathrm{C}$ pools in $\mathrm{N}$ limited systems in subtropical forests, temperate forests and grasslands, but not in N-rich subtropical forests. Our results are also supported by recent field experiments in other regions, which suggested that plant growth may not respond to increased $\mathrm{N}$ deposition in subtropical forests with $\mathrm{N}$-rich soils and high rates of soil N cycling (Cusack et al., 2010; Harrington et al., 2001; Kaspari et al., 2008; Mirmanto et al., 1999). The N saturation hypotheses also suggest that further $\mathrm{N}$ addition to an $\mathrm{N}$ - saturated system will lead to reduced plant performance (fine roots) and soil functions such as N retention and nutrient cycling (Aber et al., 1998, 1989). Decreased fine root biomass is evident from our result (Fig. 2b). Other different effects of $\mathrm{N}$ deposition on $\mathrm{N}$-limited and $\mathrm{N}$-rich ecosystems were also observed in this study: decreased MBC in Nrich subtropical forests whereas it generally increased in $\mathrm{N}$-limited ecosystems. Similarly, litter decomposition and soil respiration showed a more significant decrease in $\mathrm{N}$-rich subtropical forests than those in $\mathrm{N}$-limited ecosystems. Overall, these results clearly point out the importance of initial $\mathrm{N}$ status of an ecosystem in modifying the response $\mathrm{C}$ cycling to $\mathrm{N}$ addition, which reminds us to treat $\mathrm{N}$-rich and $\mathrm{N}$-limited ecosystems differently in modeling effects of future $\mathrm{N}$ deposition on Chinese ecosystem $\mathrm{C}$ cycle.

Our study also showed that the response of $\mathrm{C}$ dynamics to $\mathrm{N}$ addition is affected by rates of $\mathrm{N}$ addition. Interestingly the effects of $\mathrm{N}$-addition at lower rates on the measure $\mathrm{C}$ dynamics (including below-ground plant $\mathrm{C}$ pool, $\mathrm{MBC}$, litter decomposition, and soil respiration) are similar to the trends observed in $\mathrm{N}$-limited ecosystems while that of $\mathrm{N}$ addition at higher rates were similar to that observed in $\mathrm{N}$-rich ecosystems. These results showed that $\mathrm{N}$ availability, regardless of its source, can affect $\mathrm{C}$ dynamics in an ecosystem. Different $\mathrm{N}$ addition rates indicate increased $\mathrm{N}$ availability from exogenous $\mathrm{N}$, but the $\mathrm{N}$-rich vs. $\mathrm{N}$-limited comparison indicates differences in $\mathrm{N}$ availability from endogenous $\mathrm{N}$ sources. They support nitrogen saturation hypotheses from two different sides. These results suggest that even though $\mathrm{N}$ addition at lower rates has a positive effect on $C$ dynamics, the effect could turn negative when an optimal threshold level (i.e., $\mathrm{N}$ saturation) is exceeded. Because below-ground plant $\mathrm{C}$ pool, $\mathrm{MBC}$, litter decomposition, and soil respiration might be affected differently by $\mathrm{N}$ addition rates, further studies focusing on these specific pools and processes are needed to avoid uncertainties in making conclusion about the overall effects of increased $\mathrm{N}$ deposition on $\mathrm{C}$ cycling in terrestrial ecosystems on regional scales.

\subsection{Implications and future research}

In the present study, we used meta-analysis to synthesize the effects of $\mathrm{N}$ addition on ecosystem $\mathrm{C}$ fluxes and pools. These processes and pools were quantified across ecosystems and summarized in Fig. 5. However, our finding based on the currently available data is hampered by some uncertainties to be considered in future research on this topic.

$85.5 \%$ of the selected studies lasted less than four years in terms of $\mathrm{N}$ treatment duration, and all the studies lasted less than 10 years. Due to the short experiment time scales in combination with the inherently high spatial variability, it is difficult to accurately assess the changes in soil $\mathrm{C}$ dynamics, especially in the mineral soil (Chapin et al., 2002). In addition, high $\mathrm{N}$ fertilization experiments $\left(\geq 120 \mathrm{~N} \mathrm{~kg} \mathrm{ha}^{-1} \mathrm{yr}^{-1}\right.$ ) for a quit short period were commonly used in recent field experiments to simulate future N deposition. Such high $\mathrm{N}$ loads may not be realistic especially in natural ecosystems, and results from such studies could be too "artificial". Thus, we suggest that follow-up studies should focus on long-term effects of $\mathrm{N}$ deposition using more realistic $\mathrm{N}$ deposition levels.

Our analysis showed a large difference between the N-rich and $\mathrm{N}$-limited ecosystems. However, the compiled studies in our metaanalysis were mainly conducted in $\mathrm{N}$-limited ecosystems (i.e., young subtropical forests, temperate forests and grasslands), and only few N-rich subtropical forests were included. Lack of more studies from $\mathrm{N}$-rich ecosystems may influence our evaluation of the integrated response of terrestrial ecosystems to $\mathrm{N}$ addition in China. This highlights the need for additional studies in tropical oldgrowth forests, $\mathrm{N}$-fixing forests, and $\mathrm{N}$-saturated temperate forests and grasslands with different $\mathrm{N}$ deposition gradient for a better understanding of how $\mathrm{C}$ cycling is affected by increased $\mathrm{N}$ deposition under future air pollution scenarios.

\section{Acknowledgments}

We thank Drs. Xiaoming Zhu, Qinggong Mao for providing unpublished data, and Wantong Wang for drawing the Fig. 1. This study was funded by the National Basic Research Program of China (2010CB833502) and the National Natural Science Foundation of China (41473112).

\section{Appendix A. Supplementary data}

Supplementary data related to this article can be found at http:// dx.doi.org/10.1016/j.envpol.2015.07.033.

\section{References}

Aber, J., McDowell, W., Nadelhoffer, K., Magill, A., Berntson, G., Kamakea, M. McNulty, S., Currie, W., Rustad, L., Fernandez, I., 1998. Nitrogen saturation in temperate forest ecosystems - hypotheses revisited. Bioscience 48, 921-934.

Aber, J.D., Nadelhoffer, K.J., Steudler, P., Melillo, J.M., 1989. Nitrogen saturation in northern forest ecosystems. Bioscience 39, 378-386.

Boxman, A.W., Blanck, K., Brandrud, T.-E., Emmett, B.A., Gundersen, P., Hogervorst, R.F., Kjonaas, O.J., Persson, H., Timmermann, V., 1998. Vegetation and soil biota response to experimentally-changed nitrogen inputs in coniferous forest ecosystems of the NITREX project. For. Ecol. Manag. 101, 65-79.

Chapin III, F.S., Matson, P.A., Mooney, H.A., 2002. Principles of Terrestrial Ecosystem Ecology. New York.

Chapin III, F.S., McFarland, J., McGuire, A.D., Euskirchen, E.S., Ruess, R.W., Kielland, K., 2009. The changing global carbon cycle: linking plant-soil carbon dynamics to global consequences. J. Ecol. 97, 840-850.

Cusack, D., Silver, W. Torn, M., McDowell, W. 2010. Effects of nitrogen additions on above- and belowground carbon dynamics in two tropical forests. Biogeochemistry 1-23.

Fang, Y.T., Yoh, M., Koba, K., Zhu, W.X., Takebayashi, Y., Xiao, Y.H., Lei, C.Y., Mo, J.M., Zhang, W., Lu, X.K., 2011. Nitrogen deposition and forest nitrogen cycling along an urban-rural transect in southern China. Glob. Change Biol. 17, 872-885.

Fang, Y.T., Gundersen, P., Mo, J.M., Zhu, W.X., 2008. Input and output of dissolved organic and inorganic nitrogen in subtropical forests of South China under high air pollution. Biogeosciences 5, 339-352.

Friedlingstein, P., Andrew, R.M., Rogelj, J., Peters, G.P., Canadell, J.G., Knutti, R., Luderer, G., Raupach, M.R., Schaeffer, M., van Vuuren, D.P., Le Quere, C., 2014 Persistent growth of $\mathrm{CO}_{2}$ emissions and implications for reaching climate targets. Nat. Geosci. 7, 709-715.

Galloway, J.N., Dentener, F.J., Capone, D.G., Boyer, E.W., Howarth, R.W., Seitzinger, S.P., Asner, G.P., Cleveland, C.C., Green, P.A., Holland, E.A., Karl, D.M. Michaels, A.F., Porter, J.H., Townsend, A.R., Vorosmarty, C.J., 2004. Nitrogen cycles: past, present, and future. Biogeochemistry 70, 153-226.

Godbold, D.L., Fritz, H.W., Jentschke, G., Meesenburg, H., Rademacher, P., 2003. Root turnover and root necromass accumulation of Norway spruce (Picea abies) are affected by soil acidity. Tree Physiol. 23, 915-921.

Harrington, R.A., Fownes, J.H., Vitousek, P.M., 2001. Production and resource use efficiencies in $\mathrm{N}$ - and P-limited tropical forests: a comparison of responses to long-term fertilization. Ecosystems 4, 646-657.

Haynes, B.E., Gower, S.T., 1995. Belowground carbon allocation in unfertilized and fertilized red pine plantations in northern Wisconsin. Tree Physiol. 15, 317-325.

Hedges, L.V., Gurevitch, J., Curtis, P.S., 1999. The meta-analysis of response ratios in experimental ecology. Ecology 80, 1150-1156.

Hogberg, P., Fan, H.B., Quist, M., Binkley, D., Tamm, C.O., 2006. Tree growth and soil 
acidification in response to 30 years of experimental nitrogen loading on boreal forest. Glob. Change Biol. 12, 489-499.

Huang, L., Zhu, W., Ren, H., Chen, H., Wang, J., 2012. Impact of atmospheric nitrogen deposition on soil properties and herb-layer diversity in remnant forests along an urban-rural gradient in Guangzhou, southern China. Plant Ecol. 213, 1187-1202.

Hyvonen, R., Persson, T., Andersson, S., Olsson, B., Agren, G.I., Linder, S., 2008. Impact of long-term nitrogen addition on carbon stocks in trees and soils in northern Europe. Biogeochemistry 89, 121-137.

Janssens, I.A., Dieleman, W., Luyssaert, S., Subke, J.A., Reichstein, M., Ceulemans, R., Ciais, P., Dolman, A.J., Grace, J., Matteucci, G., Papale, D., Piao, S.L., Schulze, E.D., Tang, J., Law, B.E., 2010. Reduction of forest soil respiration in response to nitrogen deposition. Nat. Geosci. 3, 315-322.

Johnson, I.R., Thornley, J.H.M., 1987. A model of shoot - root partitioning with optimal-growth. Ann. Bot. 60, 133-142.

Kaspari, M., Garcia, M.N., Harms, K.E., Santana, M., Wright, S.J., Yavitt, J.B., 2008. Multiple nutrients limit litterfall and decomposition in a tropical forest. Ecol. Lett. 11, 35-43.

Laubhann, D., Sterba, H., Reinds, G.J., de Vries, W., 2009. The impact of atmospheric deposition and climate on forest growth in European monitoring plots: an individual tree growth model. For. Ecol. Manag. 258, 1751-1761.

LeBauer, D.S., Treseder, K.K., 2008. Nitrogen limitation of net primary productivity in terrestrial ecosystems is globally distributed. Ecology 89, 371-379.

Liu, L.L., Greaver, T.L., 2009. A review of nitrogen enrichment effects on three biogenic GHGs: the $\mathrm{CO}_{2}$ sink may be largely offset by stimulated $\mathrm{N}_{2} \mathrm{O}$ and $\mathrm{CH}_{4}$ emission. Ecol. Lett. 12, 1103-1117.

Liu, L.L., Greaver, T.L., 2010. A global perspective on belowground carbon dynamics under nitrogen enrichment. Ecol. Lett. 13, 819-828.

Liu, X.J., Duan, L., Mo, J.M., Du, E.Z., Shen, J.L., Lu, X.K., Zhang, Y., Zhou, X.B., He, C.N., Zhang, F.S., 2011. Nitrogen deposition and its ecological impact in China: an overview. Environ. Pollut. 159, 2251-2264.

Liu, X.J., Zhang, Y., Han, W.X., Tang, A.H., Shen, J.L., Cui, Z.L., Vitousek, P., Erisman, J.W., Goulding, K., Christie, P., Fangmeier, A., Zhang, F.S., 2013. Enhanced nitrogen deposition over China. Nature 494, 459-462.

Lu, M., Zhou, X.H., Luo, Y.Q., Yang, Y.H., Fang, C.M., Chen, J.K., Li, B., 2011. Minor stimulation of soil carbon storage by nitrogen addition: a meta-analysis. Agric. Ecosyst. Environ. 140, 234-244.

Lu, X., Mo, J., Gilliam, F.S., Zhou, G., Fang, Y., 2010. Effects of experimental nitrogen additions on plant diversity in an old-growth tropical forest. Glob. Change Biol. $16,2688-2700$.

Luo, Y.Q., Hui, D.F., Zhang, D.Q., 2006. Elevated $\mathrm{CO}_{2}$ stimulates net accumulations of carbon and nitrogen in land ecosystems: a meta-analysis. Ecology 87, 53-63.

Matson, P.A., McDowell, W.H., Townsend, A.R., Vitousek, P.M., 1999. The globalization of $\mathrm{N}$ deposition: ecosystem consequences in tropical environments. Biogeochemistry 46, 67-83.

Mirmanto, E., Proctor, J., Green, J., Nagy, L., Suriantata, 1999. Effects of nitrogen and phosphorus fertilization in a lowland evergreen rainforest. Philos. Trans. R. Soc. Lond. B. Biol. Sci. 354, 1825-1829.

Mo, J., Zhang, W., Zhu, W., Gundersen, P., Fang, Y., Li, D., Wang, H., 2008. Nitrogen addition reduces soil respiration in a mature tropical forest in southern China.
Glob. Change Biol. 14, 403-412.

Mo, J.M., Brown, S., Xue, J., Fang, Y., Li, Z., 2006. Response of litter decomposition to simulated $\mathrm{N}$ deposition in disturbed, rehabilitated and mature forests in subtropical China. Plant Soil 282, 135-151.

Mo, J.M., Zhang, W., Zhu, W.X., Fang, Y.T., Li, D.J., Zhao, P., 2007. Response of soil respiration to simulated $\mathrm{N}$ deposition in a disturbed and a rehabilitated tropical forest in southern China. Plant Soil 296, 125-135.

Nave, L.E., Vance, E.D., Swanston, C.W., Curtis, P.S., 2009. Impacts of elevated N inputs on north temperate forest soil $\mathrm{C}$ storage, $\mathrm{C} / \mathrm{N}$, and net $\mathrm{N}$-mineralization. Geoderma 153, 231-240.

NBSC(National Bureau of Statistics of China), 2014. http://www.tradingeconomics com/china/gdp-growth-annual.

Niu, S.L., Wu, M.Y., Han, Y., Xia, J.Y., Zhang, Z., Yang, H.J., Wan, S.Q., 2010. Nitrogen effects on net ecosystem carbon exchange in a temperate steppe. Glob. Change Biol. 16, 144-155.

Piao, S.L., Fang, J.Y., Ciais, P., Peylin, P., Huang, Y., Sitch, S., Wang, T., 2009. The carbon balance of terrestrial ecosystems in China. Nature 458, 1009-U1082.

Pregitzer, K.S., Burton, A.J., Zak, D.R., Talhelm, A.F., 2008. Simulated chronic nitrogen deposition increases carbon storage in northern temperate forests. Glob. Change Biol. 14, 142-153.

Solberg, S., Dobbertin, M., Reinds, G.J., Lange, H., Andreassen, K., Fernandez, P.G., Hildingsson, A., de Vries, W., 2009. Analyses of the impact of changes in atmospheric deposition and climate on forest growth in European monitoring plots: a stand growth approach. For. Ecol. Manag. 258, 1735-1750.

Thomas, R.Q., Canham, C.D., Weathers, K.C., Goodale, C.L., 2010. Increased tree carbon storage in response to nitrogen deposition in the US. Nat. Geosci. 3, 13-17.

Treseder, K.K., 2008. Nitrogen additions and microbial biomass: a meta-analysis of ecosystem studies. Ecol. Lett. 11, 1111-1120.

Tu, L.-H., Hu, T.-X., Zhang, J., Li, R.-H., Dai, H.-Z., Luo, S.-H., 2010. Short-term simulated nitrogen deposition increases carbon sequestration in a Pleioblastus amarus plantation. Plant Soil 1-14.

Vitousek, P.M., Howarth, R.W., 1991. Nitrogen limitation on land and in the sea how can it occur. Biogeochemistry 13, 87-115.

Wamelink, G.W.W., van Dobben, H.F., Mol-Dijkstra, J.P., Schouwenberg, E.P.A.G., Kros, J., de Vries, W., Berendse, F., 2009a. Effect of nitrogen deposition reduction on biodiversity and carbon sequestration. For. Ecol. Manag. 258, 1774-1779.

Wamelink, G.W.W., Wieggers, H.J.J., Reinds, G.J., Kros, J., Mol-Dijkstra, J.P., van Oijen, M., de Vries, W., 2009b. Modelling impacts of changes in carbon dioxide concentration, climate and nitrogen deposition on carbon sequestration by European forests and forest soils. For. Ecol. Manag. 258, 1794-1805.

Xia, J.Y., Wan, S.Q., 2008. Global response patterns of terrestrial plant species to nitrogen addition. New Phytol. 179, 428-439.

Xu, X.K., Han, L., Luo, X.B., Liu, Z.R., Han, S.J., 2009. Effects of nitrogen addition on dissolved $\mathrm{N}_{2} \mathrm{O}$ and $\mathrm{CO}_{2}$, dissolved organic matter, and inorganic nitrogen in soil solution under a temperate old-growth forest. Geoderma 151, 370-377.

Zhang, W., Zhu, X.M., Liu, L., Fu, S.L., Chen, H., Huang, J., Lu, X.K., Liu, Z.F., Mo, J.M., 2012. Large difference of inhibitive effect of nitrogen deposition on soil methane oxidation between plantations with $\mathrm{N}$-fixing tree species and non- $\mathrm{N}$ fixing tree species. J. Geophys. Res. 117, G00N16. 